\title{
Oxidative stress parameters in blood and urine of metal-shelf factory workers
}

\author{
Metal raf üretim fabrikasında çalışan işçilerde kan ve idrar oksidatif stres parametreleri
}

\author{
Naci POLAT, Ahmet KILINÇ, A. Suha YALÇIN
}

\begin{abstract}
Objectives: We have investigated the level of antioxidants (glutathione (GSH), GSH-reductase, GSH-peroxidase, GSHtransferase, catalase (CAT) and superoxide dismutase (SOD)), lipid peroxidation products (plasma, erythrocyte and urinary malondialdehyde (MDA)) and urinary DNA damage product 8-hydroxydeoxyguanosine (8-OH-2'-dG) in metal-shelf factory workers and compared the levels to those of a control group working in a different work area.

Methods: Twenty four workers working in a metal shelf production factory and sixteen apparently healthy male volunteers without environmental and work place exposure were included in the study. Blood and urine samples were examined for oxidative stress parameters. Measurement of 8-OH-2'-dG was by high performance liquid chromatography (HPLC), while other parameters were measured by colorimetric methods.

Results: GSH-transferase, CAT, SOD activities and plasma, erythrocyte and urinary MDA levels of metal shelf production factory workers were higher than for the control group, whereas, GSH-peroxidase and GSH in workers were lower than for controls. Moreover, while GSH-reductase activity was lower, 8-OH-2'-dG level was higher than the control group but the difference was not statistically significant.

Conclusion: As a result of increased industrialization, air pollution and hazardous working conditions there is a deterioration of the balance between oxidant and antioxidant levels which affects the structure of macromolecules such as DNA, lipids and proteins.
\end{abstract}

Key words: Antioxidants, Metal-shelf factory workers, Lipid peroxidation, Oxidative stress, Free radicals

Naci Polat

Centro Laboratories and Department of Biochemistry, School of Medicine, Marmara University, Istanbul, Turkey

Ahmet Kılınç

Oksante R\&D Laboratory, Istanbul, Turkey

A. Suha Yalçın (四)

Department of Biochemistry, School of Medicine, Marmara University, Istanbul, Turkey

e-mail:asyalcin@marmara.edu.tr

Submitted/Gönderilme: 05.10.2012 - Accepted/Kabul: 27.11.2012
ÖZET

Amaç: Bu çalışmada, fabrika ortamında çalışan işçilerin antioksidan seviyeleri (glutatyon, glutatyon redüktaz, glutatyon peroksidaz, glutatyon transferaz, katalaz ve süperoksit dismutaz), lipit peroksidasyon ürünleri (plazma, eritrosit ve idrarda malondialdehit) ve DNA hasar ürünü 8-hidroksideoksiguanozin (8-OH-2'-dG) ölçülerek işçilerdeki oksidatif stres düzeylerinin karşılaştırılması amaçlanmıştır.

Yöntem: Çalışmaya İstanbul sanayi bölgesinde metal raf üretimi yapan bir fabrikanın üretim kısmında çalışan 24 işçi ile 16 kişiden oluşan bir kontrol grubu alınmış, hastalardan ve kontrol gruplarından alınan kan ve idrar örneklerinde oksidatif stres parametreleri incelenmiştir.

Bulgular: İşçilerde glutatyon transferaz, katalaz, süperoksit dismutaz ve plazma, idrar ve eritrosit malondialdehit düzeyleri kontrol grubuna göre yüksek bulunurken, glutatyon peroksidaz ve glutatyon düzeyleri düşük bulunmuştur. Glutatyon redüktaz ve 8-OH-2'-dG değerleri kontrol grubuna göre sirasıyla düşük ve yüksek bulunmuş olmakla birlikte değerler arasındaki fark istatistiksel olarak anlamlı değildir.

Sonuç: Metal raf üretim fabrikasında çalışan işçiler kontrol grubuna göre serbest radikallerin zararlı etkilerine daha fazla maruz kalmaktadir.

Anahtar kelimeler: Antioksidan, Metal raf fabrika işçileri, Lipit peroksidasyonu, Oksidatif stres, Serbest radikaller

\section{Introduction}

Free radicals are very reactive molecules, produced continuously during the course of normal oxidative metabolism and generated by many exogenous agents [1]. In aerobic cells, most reactions of free radicals involve molecular oxygen, its radical derivatives (superoxide anion and hydroxyl radicals), and peroxides [2]. Reactive oxygen species (ROS) cause damage to cells by reacting with macromolecules such as lipids, proteins, and DNA [3]. Oxidative DNA damage can produce base and sugar lesions, strand breaks and base free sites which, if left unrepaired, play an important role in a number of disease states [4].

All cells have developed a defense mechanism against ROS which is termed the antioxidant system that includes both enzymatic and nonenzymatic components [5]. Lowmolecular-weight antioxidant molecules such as carotenoids, 
tocopherols, ascorbic acid, glutathione (GSH) and melatonin as well as different enzymes and proteins are important components of the antioxidant system. Superoxide dismutase (SOD) is the first-line of defense against oxygen-derived free radicals and catalyzes the dismutation of the superoxide anion $\left(\mathrm{O}_{2}^{-}\right)$into $\mathrm{H}_{2} \mathrm{O}_{2}$. Catalase (CAT) is present in peroxisomes in eukaryotic cells and transforms $\mathrm{H}_{2} \mathrm{O}_{2}$ into $\mathrm{H}_{2} \mathrm{O}$ and $\mathrm{O}_{2}$. GSHperoxidase, a selenoprotein, reduce lipidic or nonlipidic hydroperoxides as well as $\mathrm{H}_{2} \mathrm{O}_{2}$ while oxidizing $\mathrm{GSH}$ to generate oxidized glutathione (GSSG), which is then reduced to GSH by GSH-reductase.

The process of lipid peroxidation is one of oxidative conversion of polyunsaturated fatty acids to products of native aldehydes such as malondialdehyde (MDA) and 4-hydroxynonenal (HNE) by a well-studied, biologically relevant free radical reaction [6]. MDA measurements have been used as a general index of oxidative damage. Lipid peroxidation has been implicated in various pathological conditions, and in toxicity induced by chemicals, including certain metals [7,8]. Oxidative attack of essential cell components by free radicals is a mechanism generally recognized to be responsible for the pathogenesis of several human diseases $[9,10]$. The increase in various biological indicators of oxidative stress has been demonstrated in such situations, and the modifications could sometimes be correlated with markers of the pathological processes [11].

The air in the work environment usually contains a number of hazardous chemicals, which may pose a potential health risk when inhaled and absorbed by the body. In recent years, evidence has accumulated that interaction between air pollutants and living tissues may cause disturbances of the prooxidant/antioxidant balance of the body [12]. Occupational and environmental exposure to heavy metals such as cadmium, mercury, nickel and lead is known to cause health hazards due to their toxic action on biological systems. Metals have the potential to cause oxidative damage to various cells and tissues, including erythrocytes [13]. In this study, we investigated the level of antioxidants (GSH, GSH-reductase, GSH-peroxidase, GSH-transferase, CAT and SOD), lipid peroxidation products (plasma, erythrocyte and urinary MDA) and the urinary DNA damage product 8-hydroxydeoxyguanosine (8-OH-2'-dG) in metal-factory workers and compared the levels to those of a control group working in a different work area.

\section{Methods}

\section{Chemicals}

All chemicals were of pro analysis grade. Potassium chloride, acetonitrile, methanol and other solvents were from Merck Chemicals and 8-OH-2'-dG standard was purchased from Sigma Chemicals. Water, acetonitrile and methanol used for the mobile phase were of HPLC grade. Cartridges for solid phase extraction were from Varian (Harbour City, CA, USA).

\section{Participants}

Twenty four workers working in a metal-shelf factory and sixteen apparently healthy male volunteers without environmental and work place exposure were included in the study. Information on age, duration of present work, lifestyle and history of disease was obtained from each participant. They were working in the area for the production of metal shelves for at least $8 \mathrm{hrs}$ a day. A questionnaire was used to gather information on personal characteristics (gender, age, weight etc.), life style (smoking, alcohol consumption and healthy-eating) and occupational history (e.g., working history at plants, working environment, job titles, periods of employment and use of protective equipment). The duration of the present work was 1 to 27 years (median: 4 and 4) for workers and 1 to 15 (median: 2 and 4) for controls. Table I lists the demographic characteristics of workers and controls.

\section{Sample collection}

The study was approved by the institutional ethical committee and informed consent was obtained from both workers and controls. Blood and urine samples were collected just before the lunch break. Urine samples were collected in polyethylene bottles and were kept at $-18{ }^{\circ} \mathrm{C}$ until further analysis. Each participant provided $2 \mathrm{ml}$ of venous blood, drawn into chemically clean tubes that contained heparin. Blood samples were prepared rapidly for enzymatic analysis. The blood sample taken from each worker was centrifuged at $1,500 \mathrm{x} g$ for $10 \mathrm{~min}$ to separate erythrocytes and plasma. Serum samples were obtained following the centrifugation of erythrocytes, which were analyzed within a week. The erythrocyte suspension was washed three times in cold $0.9 \%$ sodium chloride $(\mathrm{NaCl})$ and centrifuged. For some analyses, hemolyzate was prepared from the remaining erythrocyte suspension. Plasma samples were stored at $-18{ }^{\circ} \mathrm{C}$ and analyzed within 15 days.

\section{Biochemical determinations}

All oxidant and antioxidant analyses were performed spectrophotometrically (Perkin Elmer - Lambda 25). Activities were expressed as units per gram of hemoglobin (Hb). 8-OH-2'-dG was analyzed by HPLC with electrochemical detector (ECD) (Chromsystems).

Hemoglobin in erythrocyte lysates was estimated in a cell-counter and creatinine was measured on a Cobas Integra 800 analyzer (Roche). GSH was determined by the method of Beutler [14]. The activity of GSH-reductase was measured by following the oxidation of nicotinamide adenine dinucleotide phosphate (NADPH) spectrometrically at $340 \mathrm{~nm}$ [15]. GSH-peroxidase catalyzes the oxidation of GSH to GSSG by hydrogen peroxide and the rate of formation of GSSG was 
measured by means of the GSH-reductase reaction [16]. GSHtransferase activity was determined by the method of Habig et al [17]. The rate of decomposition of hydrogen peroxide $\left(\mathrm{H}_{2} \mathrm{O}_{2}\right)$ by CAT was measured spectrophotometrically at 230 $\mathrm{nm}$ [18]. SOD was determined by the method of Sun et al. [19]. Lipid peroxidation was measured by the method of Stocks et al. [20] in red blood cells and by the method of Ohkawa et al. [21] in plasma. The pink chromogen produced by the reaction of thiobarbituric acid with MDA and other aldehydes was estimated.

Analysis of 8-OH-2'-dG was based on the HPLC - ECD system $[22,23]$. For the analytical column, a Phenomenex C18 (LiChrospher/Supersphere, 125x4 mm, $4 \mu \mathrm{m}$ ) was used with Bond Elute Certify $(10 \mathrm{~mL})$ as the pretreatment column. The pretreatment column allows the passage of hydrophilic components such as proteins first and then retains hydrophobic substances of lower molecular weight in the small pores. The mobile phase consisted of $50 \mathrm{mmol} \mathrm{x}$ $\mathrm{L}^{-1} \mathrm{KH}_{2} \mathrm{PO}_{4}, 2$ mmol x L ${ }^{-1} \mathrm{KCl}$ and $1 \%$ methanol ( $\mathrm{pH} 4.45$ ). The flow rate was adjusted to $0.5 \mathrm{~mL} \mathrm{x} \mathrm{min}^{-1}$. Urine 8-OH2 '-dG was quantified by measuring peak areas on the linear regression curve obtained for aqueous standard solutions (Figure 1). The results were given as $8-\mathrm{OH}-2$ '-dG nM / mg creatinine.

\section{Statistical analysis}

All data were expressed as means $\pm \mathrm{SD}$ and were subjected to statistical analysis using the unpaired t-test. The Chi-square statistical test was used for categorical data.

\section{Results}

There were no significant differences between the metal-shelf workers and the controls in body weight, age, smoking status and alcohol consumption (Table I). The results of antioxidant levels (Table II) and oxidative stress parameters (Table III)

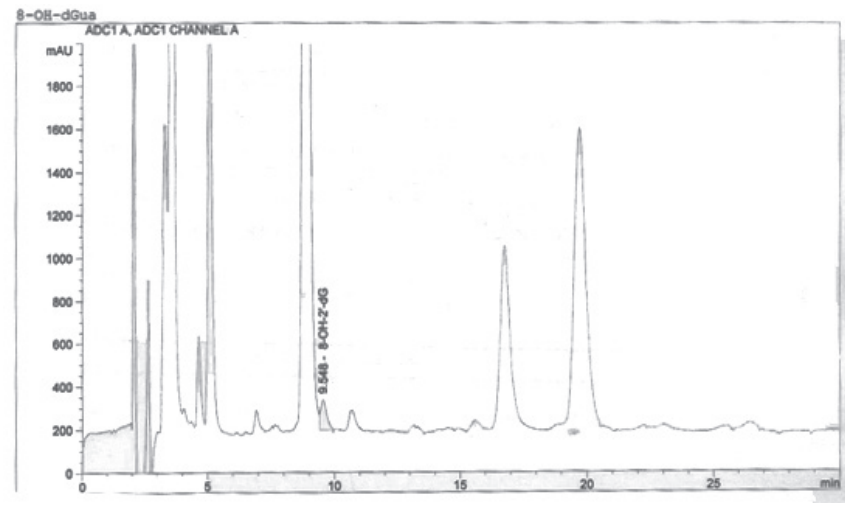

Figure 1. A sample chromatogram of 8-OH-2'-dG.

demonstrated that metal workers' GSH-transferase, CAT, SOD activities and their plasma, erythrocyte and urine MDA levels were higher than in the control group. In contrast, the control group's GSH and GSH-peroxidase levels were lower than the metal workers. Compared with the control group, the metal workers' GSH-reductase and 8-OH-2'-dG values were not significantly different $(\mathrm{p}>0.05)$, whereas their GSH $(\mathrm{p}<$ $0.0001)$ levels, GSH-peroxidase ( $p<0.0001)$, GSH-transferase $(\mathrm{p}<0.0001)$, CAT $(\mathrm{p}<0.0001)$ and $\mathrm{SOD}(\mathrm{p}=0.0424)$ activities as well as their plasma MDA ( $p<0.0001)$, erythrocyte MDA $(\mathrm{p}=0.0002)$ and urinary MDA $(\mathrm{p}=0.0093)$ levels were significantly different.

\section{Discussion}

Under normal physiological conditions, there is a balance between endogenous oxidants and antioxidants. When an imbalance occurs, created by the excessive generation of oxidants or a decrease of antioxidants, the abnormality is called oxidative stress. Reactive oxygen species produced under these conditions can then attack lipid, protein and

Table I. Demographic characteristics of workers and controls (values are mean \pm SD). Numbers in parentheses indicate range.

\begin{tabular}{|c|c|c|c|}
\hline & $\begin{array}{c}\text { Controls } \\
(n=16)\end{array}$ & $\begin{array}{l}\text { Workers } \\
(n=24)\end{array}$ & $\mathrm{p}$ Value \\
\hline Male & 13 & 21 & \multirow{2}{*}{$p=0.6678$} \\
\hline Female & 3 & 3 & \\
\hline Age (years) & $32.9 \pm 7.4(22-50)$ & $33.2 \pm 4.6(27-46)$ & $\mathrm{p}=0.8750$ \\
\hline Weight (kg) & $74.4 \pm 15(48-107)$ & $71.3 \pm 9.8(55-90)$ & $\mathrm{p}=0.4331$ \\
\hline \multicolumn{4}{|c|}{ Smoking status } \\
\hline Yes & 9 & 13 & \multirow[b]{2}{*}{$\mathrm{p}=0.999$} \\
\hline No & 7 & 10 & \\
\hline \multicolumn{4}{|c|}{ Alcohol consumption } \\
\hline Yes & 11 & 9 & \multirow[b]{2}{*}{$\mathrm{p}=0.1053$} \\
\hline No & 5 & 15 & \\
\hline
\end{tabular}

The Chi-square statistical test was performed to determine significant differences between groups.

$\mathrm{p}<0.05$ indicates a statistically significant difference. 
Table II. Antioxidant levels of workers in factories producing metal shelves and in controls.

\begin{tabular}{|c|c|c|c|}
\hline Parameters & $\begin{array}{l}\text { Controls } \\
(\mathrm{n}=16)\end{array}$ & $\begin{array}{l}\text { Workers } \\
(n=24)\end{array}$ & Significance \\
\hline $\begin{array}{l}\text { GSH } \\
(\mu \mathrm{mol} / \mathrm{g} \mathrm{Hb})\end{array}$ & $\begin{array}{c}11.6 \pm 1.6(10.0-16.2) \\
\% \mathrm{CV}: 13.5\end{array}$ & $\begin{array}{c}8.3 \pm 1.3(6.8-12.2) \\
\quad \% \text { CV: } 15.9\end{array}$ & $\mathrm{p}<0.0001$ \\
\hline $\begin{array}{l}\text { GSH-reductase } \\
(\mathrm{U} / \mathrm{g} \mathrm{Hb})\end{array}$ & $\begin{array}{c}6.6 \pm 2.7(3.0-11.2) \\
\% \text { CV: } 40.9\end{array}$ & $\begin{array}{c}6.3 \pm 2.0(2.4-10.0) \\
\% \text { CV: } 31.2\end{array}$ & n.s. \\
\hline $\begin{array}{l}\text { GSH-peroxidase } \\
(\mathrm{U} / \mathrm{g} \mathrm{Hb})\end{array}$ & $\begin{array}{c}112.6 \pm 20.3(85.8-152.0) \\
\% \text { CV: } 18.0\end{array}$ & $\begin{array}{c}84.5 \pm 18.9(8.1-111.6) \\
\% \text { CV: } 22.4\end{array}$ & $\mathrm{p}<0.0001$ \\
\hline $\begin{array}{l}\text { GSH-transferase } \\
(\mathrm{U} / \mathrm{g} \mathrm{Hb})\end{array}$ & $\begin{array}{c}23.0 \pm 10.7(10.5-53.0) \\
\% \text { CV: } 46.5\end{array}$ & $\begin{array}{l}40.4 \pm 11.2(23-62) \\
\quad \% \text { CV: } 27.7\end{array}$ & $\mathrm{p}<0.0001$ \\
\hline $\begin{array}{l}\text { CAT } \\
(\mathrm{U} / \mathrm{g} \mathrm{Hb})\end{array}$ & $\begin{array}{c}758.6 \pm 148.4(472-936) \\
\% \text { CV: } 19.6\end{array}$ & $\begin{array}{c}2215.4 \pm 824.6(169-3804) \\
\% \text { CV: } 37.2\end{array}$ & $\mathrm{p}<0.0001$ \\
\hline $\begin{array}{l}\text { SOD } \\
(\mathrm{U} / \mathrm{g} \mathrm{Hb})\end{array}$ & $\begin{array}{c}1881.9 \pm 506.5(1015-2665) \\
\% \text { CV: } 26.9\end{array}$ & $\begin{array}{c}2434.5 \pm 964.7(941-4392) \\
\% \text { CV: } 39.6\end{array}$ & $\mathrm{p}=0.0424$ \\
\hline
\end{tabular}

n.s.: not significant; $\mathrm{p}<0.05$ indicates a statistically significant difference.

Values are $\mathrm{X} \pm \mathrm{SD}$ (minimum value - maximum value); $\mathrm{X}=$ mean, $\mathrm{SD}=$ standard deviation, $\mathrm{CV}=$ coefficient of variation

All of the numerical data were statistically analyzed. Arithmetic mean (X) and standard deviations (SD) were calculated.

Unpaired t-test was performed to determine significant differences between groups.

nucleic acid simultaneously in the living cells. Many exogenous parameters such as lifestyle, smoking, alcohol drinking, working conditions, air pollution and exercise are different causes of oxidative stress [24]. Air pollution is also known to cause many acute and chronic diseases. It is an important source of reactive oxygen species, which interact with DNA and lipids, leading to oxidative stress, DNA damage and lipid peroxidation.

Environmental pollutants are abundant for workers in factories producing metal shelves and may contribute to the production of oxidative stress. In the present study, we found that both markers of oxidative damage (8-OH-2'-dG and blood and urinary MDA) and of antioxidant levels (GSH, GSH-peroxidase, GSH-transferase, CAT, SOD) in workers exceeded those of the control groups. Peluso et al. [25] measured the levels of a new biomarker of oxidative stress and lipid peroxidation (malondialdehyde-deoxyguanosine (dG) adduct) in petrochemical workers, nearby residents, and subjects living in a control district without proximity to industrial sources in Thailand. It was reported that both petrochemical-steel plant workers and people living close to industrial areas related to air pollution had high

Table III. Oxidative stress parameters of workers in factories producing metal shelves and in controls.

\begin{tabular}{|c|c|c|c|}
\hline Parameters & $\begin{array}{l}\text { Controls } \\
(n=16)\end{array}$ & $\begin{array}{c}\text { Workers } \\
(n=24)\end{array}$ & Significance \\
\hline $\begin{array}{l}\text { Plasma MDA } \\
(\mathrm{nmol} / \mathrm{ml})\end{array}$ & $\begin{array}{c}0.16 \pm 0.04(0.10-0.23) \\
\% \text { CV: } 26\end{array}$ & $\begin{array}{c}0.28 \pm 0.09(0.15-0.47) \\
\% \text { CV: } 30.4\end{array}$ & $\mathrm{p}<0.0001$ \\
\hline $\begin{array}{l}\text { RBC MDA } \\
(\mathrm{nmol} / \mathrm{g} \mathrm{Hb})\end{array}$ & $\begin{array}{c}209.3 \pm 56.2(124-293) \\
\% \text { CV: } 26.9\end{array}$ & $\begin{array}{c}381.5 \pm 163.1(99-676) \\
\% \text { CV: } 42.8\end{array}$ & $\mathrm{p}=0.0002$ \\
\hline $\begin{array}{l}\text { Urine MDA } \\
(\mathrm{nmol} / \mathrm{ml})\end{array}$ & $\begin{array}{c}0.22 \pm 0.06(0.11-0.33) \\
\% \text { CV: } 28.9\end{array}$ & $\begin{array}{c}0.31 \pm 0.13(0.12-0.56) \\
\% \mathrm{CV}: 40.6\end{array}$ & $\mathrm{p}=0.0093$ \\
\hline $\begin{array}{l}\text { Urine } \\
8-\mathrm{OH}-2 \text { '-dG } \\
(\mathrm{nmol} / \mathrm{ml})\end{array}$ & $\begin{array}{c}86.8 \pm 88.4(28.4-341.2) \\
\quad \% \text { CV: } 101.84\end{array}$ & $\begin{array}{c}146.0 \pm 129.6(45.3-517.4) \\
\% \text { CV: } 88.77\end{array}$ & n.s. \\
\hline $\begin{array}{l}\text { Urine } \\
\text { 8-OH-2'-dG } \\
\text { (nmol/mg creatinine) }\end{array}$ & $\begin{array}{l}0.9 \pm 0.9(0.3-3.4) \\
\quad \% \text { CV: } 101.15\end{array}$ & $\begin{array}{l}1.5 \pm 1.3(0.5-5.2) \\
\quad \% \text { CV: } 89.05\end{array}$ & n.s. \\
\hline
\end{tabular}

n.s.: not significant; $\mathrm{p}<0.05$ indicates a statistically significant difference.

Values are $\mathrm{X} \pm \mathrm{SD}$ (minimum value - maximum value); $\mathrm{X}=$ mean, $\mathrm{SD}=$ standard deviation, $\mathrm{CV}=$ coefficient of variation

All of the numerical data were statistically analyzed. Arithmetic mean (X) and standard deviations (SD) were calculated.

The unpaired t-test was performed to determine significant differences between groups. 
levels of malondialdehyde-deoxyguanosine (dG) adduct. A multivariate regression analysis showed that the adduct levels were associated with occupational and environmental exposures to air pollution. The highest adduct level was observed in the steel factory workers. In another study done in Copenhagen, the levels of $8-\mathrm{OH}-2$ '-dG in bus drivers working in the city were significantly higher than in bus drivers in rural area [26]. In our study, we have also found that 8-OH-2'-dG levels of workers in factories producing metal shelves were higher than in controls although the difference was not significant (n.s.).

Özgüner et al. [27] investigated the effects of noise on parameters of free radical production and the antioxidant defence system and reported that plasma MDA, erythrocyte SOD and GSH-peroxidase levels were significantly higher in weavers than in controls. Gayathri et al. [28] investigated lead toxicity and antioxidant levels in battery factory workers and reported that erythrocyte SOD activity was decreased, whereas reduced GSH was increased compared to controls. Workers who were exposed to asbestos had higher SOD, MDA and MDA/SOD values than the control group [29]. Sati et al. [30] reported that styrene inhalation by workers led to increased oxidative stress which was proposed to be the cause of lung damage. Our results have also shown that antioxidant enzyme activities (SOD, CAT, GSH-transferase) and lipid peroxidation parameters (plasma, erythrocyte and urine MDA) of workers producing metal shelves were higher than the control group.

In conclusion, all the above findings by different investigators clearly indicate that as a result of increased industrialization, air pollution and poor working conditions there is a deterioration of the balance between oxidant and antioxidant levels. For this reason, use of effective ventilation systems and improved working conditions (cooking, cleaning, work-load, shift-system, etc.) for factory workers may help reduce the risk of oxidative stress-induced diseases.

\section{Acknowledgement}

This study was supported by Marmara University Scientific Research Projects Unit (SAG-C-YLP-031210-0277).

\section{References}

1. Cheeseman KH, Slater TF. An introduction to free radical biochemistry. Br Med Bull 1993; 49: 481-93.

2. Halliwell B, Gutteridge JMC, (editors).Free radicals in biology and medicine. 3rd ed. Oxford: Oxford Univ Press, 1999.

3. Knight JA. Disease related to oxygen-derived free radicals. Ann Clin Lab Sci 1995; 25: 111-21.

4. Dizdaroglu M, Jaruga P, Birincioglu M, Rodriguez H. Free radicalinduced damage to DNA: Mechanisms and measurement. Free Rad Biol Med 2002; 32: 1102-15.

5. Gutteridge JMC, Halliwell B. Antioxidants: molecules, medicines, and myths. Biochem Biophys Res Commun 2010; 393: 561-4.

6. Gutteridge JM. Lipid peroxidation and antioxidants as biomarkers of tissue damage. Clin Chem 1995; 41: 1819-28.

7. Jomova K, Valko M. Advances in metal-induced oxidative stress and human disease. Toxicology 2011; 283: 65-87. http://dx.doi. org/10.1016/j.tox.2011.03.001
8. Sugiyama M. Role of cellular antioxidants in metal-induced damage. Cell Biol Toxicol 1994; 10: 1-22. doi:10.1007/BF00757183

9. Cross CE, Halliwell B, Borish ET, et al. Oxygen radicals and human disease. Ann Intern Med 1987; 107: 526-45.

10. Yagi K. Lipid peroxides in human diseases. Chem Phys Lipids 1987; 45: 337-51. doi:10.1016/0009-3084(87)90071-5

11. Janero DR. Malondialdehyde and thiobarbituric acid-reactivity as diagnostic indices of lipid peroxidation and peroxidative tissue injury. Free Radic Biol Med 1990; 9: 515-40. doi:10.1016/08915849(90)90131-2

12. Yang W, Omaye ST. Air pollutants, oxidative stress and human health. Mutation Res 2009; 674: 45-54.

13. Gupta A, Shukla GS. Enzymatic antioxidants in erythrocytes following heavy metal exposure: Possible role in early diagnosis of poisoning. Bull Environ Contam Toxicol 1997; 58: 198-205. doi:10.1007/ s001289900320

14. Beutler E, Duron O, Kelly BM. Improved method for the determination of blood glutathione. J Lab Clin Med 1963; 61: 882-90.

15. Beutler E. Effect of flavin compounds on glutathione reductase activity in vivo and in vitro studies. J Clin Invest 1969; 48: 1957-66. doi:10.1172/JCI106162

16. Beutler E, (editor). Glutathione peroxidase, Red Cell Metabolism. A manual of biochemical methods. 2nd ed. New York: Grune and Stratton, 1975; 71-3.

17. Habig WH, Pabst MJ, Jakoby WB. Glutathione S-transferases. The first enzymatic step in mercapturic acid formation. J Biol Chem 1974; 249: 7130-9.

18. Chance B. Catalases and peroxidases, Part II. Special Methods: Methods of Biochemical Analysis 1954; 1: 408-24.

19. Sun Y, Oberley LW, Li Y. A simple method for clinical assay of superoxide dismutase. Clin Chem 1988; 34: 497-500.

20. Stocks J, Offerman EL, Modell CB, Dormandy TL. The susceptibility to autoxidation of human red cell lipids in health and disease. Br J Hematol 1972; 23: 713-24. doi:10.1111/j.1365-2141.1972.tb03486.x

21. Ohkawa H, Ohishi N, Yagi K. Assay for lipid peroxides in animal tissues by thiobarbituric acid reaction. Anal Biochem 1979; 95: 351-8. doi:10.1016/0003-2697(79)90738-3

22. Domijian AM, Peracia M. Electrochemical HPLC measurement of 8-oxo-dG. Arh Hig Rada Toksikol 2008; 59: 277-82.

23. De Martinis BS, de Lourdes Pires Bianchi M. Methodology for urinary 8-hydroxy 2'-deoxyguanosine analysis by HPLC with electrochemical detection. Pharmacol Res 2002; 46: 129-31.

24. Schröder P, Krutmann J. Environmental oxidative stress Environmental sources of ROS. The Handbook of Environmental Chemistry Vol 2 Part O. Berlin, Heidelberg:Springer-Verlag, 2005; 1931.

25. Peluso M, Srivatanakul P, Munnia A, et al. Malondialdehydedeoxyguanosine adducts among workers of a Thai industrial estate and nearby residents. Environ Health Perspect 2010; 118: 55-9.

26. Loft S, Poulsen HE, Vistisen K, Knudsen LE. Increased urinary excretion of 8-oxo-2'-deoxyguanosine, a biomarker of oxidative DNA damage, in urban bus drivers. Mutat Res 1999; 441: 11-9.

27. Özgüner MF, Delibaş N, Tahan V, Koyu A, Köylü H. Effects of industrial noise on the blood levels of superoxide dismutase, glutathione peroxidase and malondialdehyde. East J Med 1999; 4: 135.

28. Gayathri MR, Beena VS, Sudha K. Evaluation of lead toxicity and antioxidants in battery workers. Biomed Res 2007; 19: 1-4.

29. Kamal AA, el Khafif M, Koraah S, Massoud A, Caillard JF. Blood superoxide dismutase and plasma malondialdehyde among workers exposed to asbestos. Am J Ind Med 1992; 21: 353-61. doi:10.1002/ ajim.4700210308

30. Sati PC, Khaliq F, Vaney N, Ahmed T, Tripathi AK, Banerjee BD. Pulmonary function and oxidative stress in workers exposed to styrene in plastic factory: occupational hazards in styrene-exposed plastic factory workers. Hum Exp Toxicol 2011; 30: 1743-50. doi: $10.1177 / 0960327111401436$ 